DOI: $10.15642 / J I I S .2014 .8 .1 .71-90$

\title{
THE SOCIAL DISCRIMINATION AGAINST FORMER TERRORIST CONVICTS AND THEIR FAMILIES Psychological Perspectives
}

\author{
Siti Nur Asiyah, Nailatin Fauziyah, Siti Khorriyatul Khotimah, \\ Soffy Balgies \\ Department of Psychology, UIN Sunan Ampel, Surabaya - Indonesia | \\ nurays72@yahoo.co.id
}

\begin{abstract}
This study examines the social discrimination against the former terrorist convicts and their families. It is aimed at knowing about former terrorist convicts' family patterns of community interaction, the growing social discrimination within the social life of former terrorist's convicts' family, the impact of social discrimination against the family of former terrorist convicts, and the coping behavior of former terrorist convicts over that situation. This study uses descriptive qualitative research methods. The study finds that the pattern of interactions between the family of former terrorist convicts and their surrounding communities can be divided into two phases, before and after the arrest. It also maintains that the social discrimination against the family of former terrorist convicts occurs when they are dealing with people outside the village of Tenggulun, in the form of isolation, token and reserve discrimination. The prejudice and social discrimination on the family of former terrorist convicts impact on their self-worth, self-esteem and well being. Coping behavior by former terrorist convicts and their families are two kinds, namely emotion focused coping and problem-focused coping.
\end{abstract}

Keywords: Social discrimination, terrorist, terrorist family.

\section{Introduction}

The world gives full attention towards the cases of terrorism after the events of the WTC (World Trade Center) New York, United States on September 11, 2001 and the Bali bombings on oktober 12, 2002. Of the cases, the UN (United Nations) compelled to issue a resolution 
No. 1373 of 2001 and Resolution No. 1438 dated on October 15, 2002 as the official stance of the official world that terrorism can be classified as crimes against humanity and extraordinary crime. Resolutions no. 1373 and 1438 show the concern of the international community over the second incident of terrorism.

These events disrupt the stability of the nation and society. People feel uncomfortable to perform activities in daily life, as well as the followers of worship, especially Christians, where in carrying out religious activities coupled with uncomfortable feelings and fears of terror bombings in their places of worship. This situation also raises the pressure on the State to take responsive action to the issues concerning on security and peace of the community, which is free from terrorism.

Lately, government made efforts to combat terrorist with repressive approach, which is one of the focus on hunting terrorists and their criminal networks. Detachment 88 is a representative of the government in tackling the crime of teorism. They undertake maximum efforts to combat terrorism in Indonesia. It can be seen from the data of some terrorist arrested e.g. trio Bali bomber (Imam Samudra, Mukhlas, and Amrozi), Ali Imron, Abu Bakar Bashir, Nurdin M. Top, the terrorist network in Cirebon, Solo, Pamulang, and so on.

The act of bombings that were carried out by terrorists resulted in many casualties from both non-Muslims and Muslims, such as 202 people died and 300 people were injured by bomb blasts in Bali on October 2002. Moreover 22 people died and 102 people were injured due to the bomb blasts in Bali on October 2005. The victims died and others were injured in an explosion events in several cities in Indonesia. This serial of events makes the Indonesian people feel angry and hurt. The actions of the terrorists has come under fire because it is considered as inhumane acts.

Almost every day variety of media, both print and electronic media talk about terrorism and the hunt of Detachment 88 for the perpetrators of terrorism. This further reinforces the public perception of the terrorist groups and their networks that are in Indonesia. Communities tend to develop negative perceptions of the perpetrators of terrorism and their networks. The public perception will affect how public attitudes towards criminal terrorist and his family. According to Anwar $(1995,30)$ the formation of a person's attitude is influenced by personal experience, the influence of other people that are considered 
important, the influence of culture, media, educational institutions, religious institutions, and emotional factors. This is in line with the AA family worries (suspected terrorist network in Cirebon) when Detachment 88 arrested one of his family on May 22, 2011. AA's father in law said: "We are very embarrassed when the police came to his house. We worry if all his family is also considered as terrorist". Since then, they also felt that public treat them differently from others. ${ }^{1}$

Discrimination against the former terrorist convicts is a different form of treatment to their communities and families with other community members. They and their families deserve to be labeled as negative and to be punished by restricting their movements in social life. For example, people tend to identify the people who approach them as an accomplice, so they let them and their families live isolated from their social environment. As a result, people are reluctant to cooperate with them in any field of activities. The society forget that they are also social creature who naturally feel depressed when the surrounding environment positioned them as a group that should be isolated. ${ }^{2}$

This social discrimination occurs as a result of social prejudice against former terrorist groups. According to Brehm and Kassin, social prejudice is a negative feeling toward a person based solely on their membership in a particular group. Meanwhile, according to David O. Sears et al., social prejudice is a justification of an individual or a group that is mainly based on the group membership, meaning that social prejudice directed at a person or group of people who differ with him or his group. Social prejudice have quality of likes and dislikes on the prejudiced objects, and this interferes with the actions or behavior of a person who is prejudiced.

Social discrimination gives psychological impact on society. This study aims to examine the relationship between racial and ethnic discrimination in 2047 Asians (immigrants and US-born) in the United States. It shows that there is a relationship between racial and ethnic discrimination experienced with the stress level. Ethnic Identity give a negative impact on the mental health.

\footnotetext{
1 http://news.okezone. com/read/2011 / 05/24/337 /460196/keluarga-aa-cemasdicap-teroris

${ }^{2}$ Results of the interviews with ex-terrorists convicts on July 13, 2011.
} 
The social reality that gave rise to the phenomenon of social discrimination against the former terrorist convicts puts a psychological impact on members of their family. These conditions will be explored further in order to uncover the true facts regarding former terrorist convicts and their families.

Referring to that background, this study aims to examine (1) the social interaction of the family of former terrorist convicts and society; (2) the forms of social discrimination against the family of former terrorists; (3) the impact of social discrimination against the family of former terrorists; and (4) family coping behaviors of former terrorists over the situation.

Research on sosial discrimination against the family of former terrorist prisoners was conducted in the village of Tenggulun Selokuro Lamongan, where family of the deceased Amrozi and Mukhlas live. Amrozi's family has been recognized as the founder of Pondok Pesantren (Islamic boarding school) Al Islam that developed the ideology of radicalism.

This research uses descriptive qualitative method, the data used in this study is qualitative data emphasizing the depth and integrity of the subject under study within a limited area. The characteristics of the data model of this study is understood in the context of inter-related unity and emphasizes the depth and integrity of the object studied.

Data collection techniques in this study include documentation, observation, and in-depth interviews. The subjects in this study include: the family of terrorist, the surrounding community (neighbors), and community leaders in Tenggulun.

Analysis of the data in this study refers to the opinion of Miles and Huberman (1992), that is conducted through three stages: data reduction, data display, and conclusion. Data reduction is the process of selecting, focusing on simplification, transformation of raw data obtained from field records. This process runs during the study, in which researchers conduct data classification problem based on the topic of research. Data display is a set of information (in the form of narrative text, equipped with matrices, graphs and charts, in order to combine structured information in a form suitable to research problems) that allow for drawing conclusions and taking action. The 
last stage is making conclusions and verification. Conclusions are drawn up based on the results of the data reduction and presentation. ${ }^{3}$

Once the data is collected, then validity check is performed to avoid any bias due to the crux of data. Validity check of the data is done through two ways, namely: perseverance observation and triangulation.

\section{Social Interaction between Terrorist Family and Society}

There are differences in the family interaction pattern of former terrorists convict with the surrounding communities before and after be convicted. Before the bombings which dragged Amrozi and some other families as the convict of terrorists, Amrozi's family that is a large family of Pondok Pesantren Al-Islam is a pretty exclusive family. They do not do any social interaction as other community members, except in some certain activities, such as shopping. But after getting out of prison, social interaction between the families and society becoming more open.

The phenomenon was recognized, both by the former terrorist convicts and their families, as well as by the surrounding community.

"In the past, before the incident (Bali bombing), our family severely limit relationship to the surrounding community, even to fellow members of Jamaah Islamiyah that we does not know, because at that point we did feel being the exclusive group, but after we, especially me, living life in the prison, we were getting a lot of lessons and experiences, which then change our thinking to be more open with others, because we feel that the message of Islam must be spreaded as wide as possible, rather than on the limited and narrow group. Changes in thinking was brought to family life after prison. We and our families are more accepting and mingle with people outside our family and our group. Since then, our social life become as befit as other members of communities," said Sumarno. ${ }^{4}$

Besides the former convicts of terrorists are starting to realize that social communication is important in establishing social interaction

${ }^{3}$ As can be seen in MB Miles and AM. Huberman, Qualitative Data Analysis: Resource Book, About New Method Method (Jakarta: UI Press, 1992).

${ }^{4}$ Interview on November 22, 2011. Ustadz Sumarno also admits that lately he met many clerics. These meetings made him getting new knowledge and indirectly affect his attitude to the public. . 
and as a form of social responsibility, residents of Tenggulun are also open an opportunity to interact and communicate with former convict of terrorists and family. There are times when social spaces can bring them together. As the statement delivered by the head of the local village 5 .

"In the past, the family of Amrozi did not get out much, but since the arrest until now, they has been able to blend in with society. For example, they are involved in community service, activities of youth clubs, activities in memorial of Islamic holidays, as well as Idul Adha, they also distributed sacrificial meat to the surrounding community".

However, in relation to religious activity, they are still perceived that their space is limited. They can only perform religious activity in Pondok Pesantren Al Islam and among Muhammadiyah members, while Nahdliyin members which constituted the majority of the citizens of Tenggulun still restrict themselves from Pondok Pesantren Al-Islam missionary activity, as said by Ustadzah Aisha ${ }^{6}$

"Students of TPA/TPQ Al-Islam boarding school came from surrounding communities, they are the children of mothers who become the members of recitation of Aisyiyah of Al-Islam boarding school. 'Statement was also justified by Sumarno, his wife and the village head; Sumarno and his wife stated that' our propaganda activities in the village is still limited among Muhammadiyah members, while access to able to penetrate the proselytizing activities among nahdliyin still hard to do".

The view of the terrorists families on how social interaction between family boarding and society is in line with public perception presented by the village head of Tenggulun. He states:

"For religious activities, such as prayers group, recitation, and taklim are still in the group. In fact, they have each mosque to pray and jum'atan, taklim and also recitation, which nahdliyin remain in the group, Muhammadiyah remain in the group, and family Al Islam boarding school was the group of Muhammadiyah. Nevertheless, till now

\footnotetext{
${ }^{5}$ Interview on November 22, 2011. At the times of the Bali bombing-indeed society had requested to the local government that the PP. Al Islam should be disbanded there are activities that can disturb society.

${ }^{6}$ Interview on November 22, 2011. Ustadzah Aisha is one of the teachers in PP. Al Islam.
} 
there is no conflict due to the issue of religious activities. One another has already understand each position as a group. We do not interfere each other no matter our origin of'.7

Growing conflict in Tenggulun villagers seems more dominated by the cultural conflict between one group with another group. Differences in defining religion and in religious rituals are often the reason why social conflicts occured between them. However, the positive side is Tenggulun villagers were able to put the conflict on its portion. In social spaces which require cooperation, they are able to work well together.

\section{Social Discrimination}

Social discrimination is not perceived either by the ex- terrorist convicts or their families when they interact with the surrounding community in the village of Tenggulun, because some of them have been able to understand the differences that occur, and they are at their respective positions. As ustadzah Fatimah (ex-convicts wife of a terrorist, Sumarno) admittes:

"There is no problem for me as well as my kids even though my husband had been imprisoned as a terrorist convicts, my kids can hang out with his friends at school with no load, even when my kids play outside, my neighbors also pay attention and keep them, no problem". 8

However, when they interact with people far outside the village of Tenggulun, different treatments are still felt. As Sumarno recognizes: ${ }^{9}$

"When I meet a foreigner, I don't say that I am from Tenggulun. I said I am from Paciran because my office is in Paciran. But after some times, they also asked about my address. When I said Tenggulun, his face instantly changed and even canceled to join in my travel agent. Similarly, when there are few female students who study in one of PTAIS, they also had to get different treatments because they use santri robes and veiled clothing during class".

\footnotetext{
${ }^{7}$ Interview on November 22, 2011

8 Interview on November, December 22, 2011. Ustadzah Fatimah is the wife of convicted terrorist, she is from West Java.

${ }^{9}$ Interview dated on October 12, 2011. Once out of prison, Sumarno do Umrah travel business trip. His office is located in the town of Lamongan Paciran.
} 
The media has a role in shaping public perceptions and attitudes. Communities that do not interact directly with the boarding family does have a negative perception about Tenggulun citizens, especially the use of the veiled Muslim fashion. Intense media attention focused on the perpetrators of terror mostly from Tenggulun contributed to the formation of public perception that Tenggulun is a terrorist area or radical Islamic networks. These perceptions will influence public attitudes in response when interacting with citizens of Tenggulun, especially they who used Muslim dress which is not generally used by the Indonesian Islamic community.

However, ex-convicts terrorist and their families are actually getting preferential treatment from officials government. As Sumarno and Khozin maintain: ${ }^{10}$

"If there is illegal logging in the woods for example, before the police take action against the thief, they first asked for information and suggestion in advance to us. We also just received a call from the police relating to the illegal logging to ask for consideration, they (police) often come here for consultation about a few things".

According to their families, that is done by the late (Bali bomber Duo) is a remarkable act, which not everyone has the ability to take a stand as they take. This makes them feel proud on both deceased, as well as people who have a common understanding on the matter. As dictated by Khozin. ${ }^{11}$

"The late (Amrozi and Ali Gufron) are the extraordinary people. Not everyone is willing to take their path, including me. I see that all they do have a positive influence on our family, all because of the courage of the late .....".

The boarding family felt that since the Bali bombing, the attitude of the public and various stakeholders is different. Boarding schools family feel that they are considered to be those who have the religious ability and courage more than others. Therefore, the boarding family now feel easy to access the things associated with the government, for instance facility. This is consistent with the information given by the head of the local village 12

\footnotetext{
${ }^{10}$ Interview on October 12, 2011.

11 Interview on October 12, 2011. Khozin admires the courage of Amrozi and Ali Gufron. He stated this repeatedly.
}

12 Interview on 22 November 2011. 
"If the village government submitted a proposal to the government, for example for the construction of roads or the other,it is rather difficult to break, but if there is a soliciting proposals from $\mathrm{Al}$ Islam, such as requests for animals aid to the governor, it's easy".

The facilitation in accessing government networks can cause social jealousy between boarding family and the village or local government. This is for the reason that the provision of assistance in general administrative procedure passes through the village administration, but the boarding family does not go through the process.

"Residents also sometimes talked about the facility obtained easily by the lodge, for example cows and goats contribution from government, and other facilities. In practice, if there is no control, so the facilities is greater" said village head. ${ }^{13}$

\section{Coping Behavior of the Terrorist Family under the restrictive circumstances}

The arrest of Bali bombings terrorist surprised many people. The ones who turned out to be the culprit are brothers from the village of Tenggulun. It is of course a hard blow for the family of Pondok Pesanten Al-Islam Tenggulun, where 6 members of their family including the Bali bombing are suspected. Among 6 members of the family, 2 persons have to undergo the death penalty, 1 person serving a sentence of life imprisonment, while 3 others serving several years in prison. When some members of the family of Al-Islam dragged to jail for being a suspected of terrorist, the family also feel anxiety. This is because the perpetrators of terror have families, children, and wives. as delivered by Sumarno's wife. ${ }^{14}$

"When my husband was arrested, initially I felt so stressfull, what about his state of condition, but after a long time, I can face everything with courage".

Although the situation is very difficult, the families of boarding school try to deal with the situation wisely. As Khozin suggests: ${ }^{15}$

"As soon as, some of the family has been caught, we do not feel burdened, because we felt that they were fighting for a principle that is believed to be the truth, even though the

\footnotetext{
${ }^{13}$ Interview on 22 November 2011

${ }^{14}$ Interview on 22 November 2011

${ }^{15}$ Interview on October 11, 2011.
} 
principle is different from the others. They do jihad was not without basis, because they are directly involved and witnessed violence committed against Muslims in other places, so that they feel that the war was an obligation as the obligation of fasting in the month of Ramadan, and it is not a problem for us. In fact, the capture of some of my family doesn't make the people here away from the boarding school, the community is still in need of our role. Thus, all of it is a consequence of a principle".

The expression above also shows that the family is mentally prepared to face all the worst that will happen to his family members. They already knew each other from the activity of each member of the family, and its values are believed to be the principal. It seems that this boarding family has the same understanding of jihad and defending the truth.

Death sentences for two family members are actually a bad news, especially for $\mathrm{Hj}$. Tariyem. She was not willing when her two sons were executed. A few days Hj. Tariyem feel so sad because of the situation.

"mesakke ibune nangis wae, jenenge wae anak'e. Wong tuwo yen kelangan anak yo sedih, opo maneh iki loro mas..."

"I am sorry for their mother who always crying. Of course, as a mother she will be sad if she lost her 2 sons ....-red", said a mother ${ }^{16}$, the neighbors of Amrozi.

While Sumarno, the former convict of terrorist, out of prison, he tried to open up more with the local community and other communities, such as religious scholars, community leaders, and the local government officers. This attitude makes him feel more confident and more open to think about Islamic propaganda. Before imprisonment, he did preach only in specific communities with specific themes, as well as he did not want to discuss matters relating to khilafiyah, avoid interacting with the Jama'ah Islamiyah that is not belong to his group. However, an open attitude makes him finds new ways and strategies in preaching, i.e. in a manner consistent with the conditions and circumstances existing in community, and not use violence.

${ }^{16}$ Interview on November 22, 2011 


\section{Discussion}

\section{Patterns of Social Interaction}

When the process of social interaction has entered the pattern stage, then the social process in society will create social order. ${ }^{17}$ The evidence suggests there are differences in patterns of family interaction of ex-convict terrorists with the surrounding communities before and after be convicted. Before the bombings that dragged Amrozi and some other families as the convict of terrorists, Amrozi family which is actually a large family of Al-Islam is a pretty exclusive boarding family. This family is very closed to the surrounding community. They do not do social interaction as other community members, except in very narrow limits, such as shopping to the store or to shop. But after getting out of prison, the social interaction between families boarding and society become more open.

As the concept presented by Soekanto (2006), that social interaction is the key of all social life because without social interaction there will be no life together. Meets the mere bodily individuals will not result in social life. The social life will only happen if every people in the association was involved in an interaction. Social interaction is a reciprocal relationship that is manifested in the form of social contact and communication. ${ }^{18}$

It is apparent to the family of former terrorist prisoners that are starting to realize that social communications are important in establishing social interaction and as a form of social responsibility. Tenggulun residents also open an opportunity to interact and communicate with the former convict of terrorists and their family. This is done because the main requirement of social interaction are: (a) the existence of social contact between the two parties, and (b) social communication between the two sides have met. ${ }^{19}$

There are times when social spaces can meet them with others, such as youth clubs, celebration/anniversary, community services and

\footnotetext{
17 A.M. Rose, Sociology, the Study of Human Relations, Second edition (New York: Alfred Knopf, 1965).

18 See Soerjono Soekanto, Sosiologi Suatu Pengantar (Jakarta: PT. Raja Grafindo Persada, 2006).

${ }^{19}$ See J. Biesanz and M. Biesanz, Introduction to Sociology (New Jersey: Prentice Hall Inc. Englewood Cliffs, 1969); Soerjono Soekanto, Pengantar Sosiologi (Jakarta: PT. Raja Grafindo Persada, 2002).
} 
so on. This is a process of social interaction in the form of cooperation or association that has a positive functions, such as: (a) the achievement of life goals of individuals or groups is easier to realize; (b) promoting the establishment of a pattern of life of individuals or groups in an integrated manner, (c) improving the quality of social roles of each individual in the lives of diverse groups; (d) promoting the development of a positive mental attitude to every individual in the social processes, and (e) encouraging the birth of innovations in various fields towards civilized society. Through this social interaction, they get to understand each other, and the surrounding communities may interact more easily.In addition to interact with the community, this family also developed some creative ideas such as making Hajj and Umrah services, farming and livestock business. However, in relation to religious activity, they are still perceived the space is limited. They can only perform religious activity in Al Islam boarding school and the Muhammadiyah, while nahdliyin residents which constituted the majority of the Tenggulun citizens still restrict themselves from $\mathrm{Al}$ Islam family missionary activity.

\section{Covert Discrimination}

Social discrimination against the former terrorist convicts and their families are plotted in several forms, namely isolation discrimination, ie the hostile acts committed by the dominant racial or ethnic group to subordinan without the immediate support of the interests of the subordinan. So, discrimination action seeks to isolate individual or target group.

Similarly, when there are few female students who study in one PTAIS, they could not hide their identity by wearing robes and veiled. Then the people around them will respond differently and seem to keep their distance. This action is clearly a hostile act committed by most people toward a group of people who identify themselves with $\mathrm{Al}$ Islam Islamic boarding school or Tenggulun village.

In general, people outside the village of Tenggulun still impressed to protect themselves against everything that related to Amrozi, Al Islam boarding school, bearded man, black-robed and veiled women, Tenggulun and Solokuro. Either recognized or not, these actions are discriminatory acts in order to isolate the groups with identity as mentioned above. This action can not be separated from the existence of social prejudice, according to Papalia and Sally, is the negative attitude aimed at others that are different from the group without any 
fundamental reason on the private person. Social prejudice is shown by the process of generalization to other group members act, in this case is a terrorist group act. According to Ancok and Suroso, if there is one individual from outside groups act negative, it will be generalized to all members of outside groups. Meanwhile, if there is one individual who did the negative of the group itself, then the negative actions will not be generalized to other members of their own group. ${ }^{20}$

The emergence of social prejudice may occur due to differences in belief systems, in which belief systems serves as the anchor for the individual. The similarity of belief between individual and congruent belief system is said to be a validation toward belief held. Thus, congruence serves as a reward, and it raises the attractiveness and positive attitudes towards parties who confirm his belief. So an individual or group will feel appropriate if they are similar in belief systems. In contrast, non-congruent belief system will lead to negative attitudes, such as between the public in general and terrorist groups. So the appearance of prejudice may be caused by the differences between one self and the outgroup. Grudge against the out group is not due to the membership in the group, but it is caused by the differences between the belief system and outgroup belief system.

On the other hand, the social discrimination against the former terrorist convicts and their families is the discrimination in the form of tokenism that is the lack of positive behaviors to the minority. This behavior is later used as a defense and justification that one had done a good thing that does not violate discrimination. For example, recognition of Sumarno and Khozin that when there is an illegal logging. So then before the police take action against the thief, the police first asked for information and suggestion in advance to some ex-convicts terrorists in Al Islam boarding school. This action is actually an attempt to deny of the existence of discrimination against the terrorist groups, by means of lifting and involving some of them in decision making.

In addition, there is also a discrimination in the form of Reserve discrimination. This is more extreme form of tokens, a discrimination practice that benefit those who are usually the target of prejudice and discrimination with the intent to obtain justification and free from

20 D. Ancok,. "Ketidakadilan Sebagai Sumber Radikalisme Dalam Agama Suatu Analisis Berbasis Teori Keadilan Dalam Pendekatan Psikologi," Jurnal Psikologi Indonesia, No. 1 (2008). 
accusations of have been doing prejudice and discrimination. For example, the statement given by the local village chief that the filing of the petition in the form of a proposal made by the family of Al-Islam boarding school to government receive more attention than the submission of a proposal made by the village government.

Therefore reservase discrimination give benefit to the group of minority, then the short-term effects can be felt immediately. For example, some of the proposed contribution of the government in the form of livestock, bio-gas, and so forth, can immediately be felt by them. But as the time goes by, there are negative consequences that can be paid by minority groups, such as in the long-term, social jealousy will emerge from the surrounding community that can result in isolation discrimination against groups that previously "are spoiled" by the government.

This preferential government treatment contains two meanings, first, the government tried to establish interaction with the ex-convicts terrorists and their networks to enable the intensive interaction. In these interactions, it is expected there will be a process of discourse and information transformation so as to change the mindset of religious radicalization. And here, the prejudices of the former convict of terrorists and their networks about state or government will turn into a positive perception that leads to sympathy. Second, the state in this case the government is conducting covert discrimination, where the kindness given to former prisoners and their families are as a form of attitude of the state, that the state does not discriminate on its citizens. This preferential treatment is expected to change the view of the former convicts of the terrorists toward state, and do not consider the state as an enemy.

Apart from the various purposes of government gives preferential treatment to former terrorist prisoners and their families, the attitude of the government and the staff have provided a major influence on self-concept of ex-prisoners and their families. They increasingly feel confident that what they are doing and believe is right, because it is perceived to have a positive effect on psychology, social, economy, and politic.

The status of the ex-convict terrorists or their family allows them to build networks and open access to both the community and government level. For example, changes in the public acceptance around the family of Al-Islam boarding school, opening the network 
with the local government, regional, and national, as well as the more intense communication at the international level. The genealogy of radical ideology that developed in the family of Al-Islam boarding school should be a government vigilance.

\section{The Impact of Prejudice \& Social Discrimination}

Based on the acknowledgment of the ex-convict terrorists and their family, some facts are obtained in the form of data that shows the impact of social discrimination they experience from outside the Tenggulun community or government.

1. Make them have self-worth, self-esteem and well being. ${ }^{21}$ This corresponds to the fact that since the exit of the prisoners, Sumarno and their families get preferential treatment from officials government. For example when there is illegal logging in the forest, the police first asked for the information and consideration to Sumarno and his family. This position makes Sumarno and his family have self worth higher than before because now their opinions and suggestions are useful for others. They also feel valued ( self esteem ). Self esteem is also formed, as Sumarno and his familiy feel that they are considered to be those who have the religious ability and courage than others. Another fact shows that there is soliciting proposals from Al-Islam, for example, the requests for animals contribution from the governor is easily obtainable. This facilitation will make family life of ex-convict terrorists more prosperous (well being).

2. Sumarno often perform denial to people who just he knew. He will not say that he comes from Tenggulun as to avoid rejection of the new people he knew.

3. Third, the fact nevertheless shows that Sumarno and his family are now changing their propagation models become more universal than the first that uses models of violent jihad. This refers to the scores. Here, Sumarno and his family tried hard to prove that the public prejudice was wrong, rejected the assumption that his group is bad.

If in the first the family of Amrozi rarely leave the house, but since the arrest until now, they has been able to blend in with society. Now

${ }^{21}$ Carol Brown, Sosial Psychology (California: SAGE Publications , 2006); Rupert Brown, Prejudice. Menangani "Prasangka" dari Perspektif Psikologi Sosial (Yogyakarta: Pustaka Pelajar, 2005). 
they are more able to accept and get along with other people outside the family and group. Since the events of the arrest until now, their social life as befits as members of other communities. Now they are trying to be open to the surrounding community and other communities, such as religious scholars, community leaders, and the state apparatus. This attitude makes him feel more confident.

\section{Coping Behavior}

The impact of prejudice and social discrimination experienced also gave rise to the behavior of emotion focused coping. ${ }^{22}$ The former terrorist convict and their family attempt to manage their emotions in order to adjust to the impact caused by a condition or stressful situations. The pressure experienced from the process of arrest, the news media, the guard of the pesantren (boarding school) by special forces, courts and detention process. They used a cognitive approach in emotion focused coping that they experienced. Here they were able to see something good out of trouble. They seek wisdom behind the incident.

Moreover the problem focused coping is emerged..$^{23}$ This coping form is visible to Sumarno and family who believe the existence of the consequences of the principle differences between society and them. Thus they do not feel any pressure or interference due to the reality actually happens, because it is a consequence of the different principle.

Other forms of problem focused coping by former convicts of terrorist acts, Sumarno is when he out of jail. He becomes more open to the surrounding community and other communities, such as religious scholars, community leaders, and the state apparatus. In addition, prior to entering prison, former terrorist prisoners preach only in specific communities with specific themes, as well as don't want to discuss matters relating to khilafiyah, and avoid interacting with his outer group in the Jama'ah Islamiyah in. Now, he is more open to think about the Islamic da'wah.

In the past, jihad propaganda was only done. Now, it is turned into a universal model of propaganda. They find ways and new strategies in preaching, i.e. in a manner consistent with the conditions and circumstances existing in community and not by violence. Now, it starts to customize propaganda by looking at the circumstances before

\footnotetext{
${ }^{22}$ John W. Santrock, Adolescence (Jakarta: Penerbit Erlangga, 1996).

${ }^{23}$ Ibid.
} 
making propaganda. Part of the propaganda carried out today is travel Hajj \& Umrah business, as well as group farming.

\section{Conflict Anatomy in Society}

The conditions of Tenggulun villagers who tend to be pluralist which consists of various streams of religion is prone to social conflict. This village is predominantly by Nahdliyin. Muhammadiyah has a smaller population than the Nahdliyin. Nevertheless, the Muhammadiyah movement in the small village of Tenggulun quite dynamic.

If the family tree of Al-Islam boarding school is identified, it can be seen that the boarding schools actually have long developed a Wahhabi ideology brought by H. Sulaiman from Saudi Arabia in the 1920s. Wahhabi ideology tends to lead to a radical understanding. H. Sulaiman ever established a boarding school in Tenggulun as a medium to develop the ideology, but in reality people are less able to accept it, and the boarding schools are not experiencing significant growth. Feeling less a place as Wahabis, the family tends to lead to Masyumi boarding school. But in this time the movement of Masyumi had not developed dynamically. Finally it tends to Muhammadiyah (as expressed by Sumarno).

There are two major organizations in Indonesia, NU and Muhammadiyah, in which the movement of these organization is known for experiencing frequent differences. The differences of understanding or interpretation of the teaching often becomes horizontal conflict at the grassroots. Conflicts that often happens strengthening group identity within the community. It results on a clear separation, in-group and out-group. As shift in the grassroots level about two groups in various parts of Indonesia, as well as which occurred in the village of Tenggulun that majority of the residents is Nahdliyin.

Each of these groups tend to categorize themselves as in-group and those in the other group as the out-group. This categorization can lead to ingroup and outgroup. Someone in the group will perceive themselves as in-group and others is perceived as an out-group. Consequently, in-group members would perceive others in-group to have in common when compared with members of out-groups. It is often referred to the similarity effect. Thus, there is an assumption that the state of the ingroup have different properties to the outgroup. Categorization of ingroup and outgroup having an impact that ingroup is 
more favorite than outgroup. It is often referred to ingroup favoritism effect . Someone in the ingroup, view outgroup is more homogeneous than the ingroup both in terms of personality as well as in other things, referred to the outgroup homogenity effect. The things mentioned above may cause prejudice to one another. When these prejudices continue to evolve, it can lead to a negative attitude toward the object of prejudice, and discriminatory behavior will finally occurs.

Conflict happen between two groups in the village of Tenggulun is a latent conflict between the two organizations in Indonesia. However, since the event, both parties began to open up and build positive communication, so that the barriers of prejudice increasingly deleted. For example, the opening to conduct joint activities on the name of public interest, such as community service, mutual cooperation, August 17 celebration (independence day celebration). Such things will eventually create inter-religious harmony.

\section{Conclusion}

This study reveals some significant points: (1) The pattern of interaction between the family of former terrorists convict and surrounding communities can be divided into two phases, namely the phase prior to the arrest, which the families of former terrorist convicts being exclusive and closed with the surrounding community, and the phase after the arrest, which the families of former terrorists be more open to the surrounding community; (2) Social discrimination against the former terrorist convicts and their families in the form of a pattern of isolation discrimination, tokenism and reserve discrimination; (3) The impact of prejudice and social discrimination on the family of former terrorists convict is a self-worth, self-esteem and well-being, denial and change of propagation models become more universal than the first that uses a model of jihad by force; and (4) there are two kinds of coping behavior committed by ex-prisoners of terrorists and their families, namely the iemotion-focused coping and problem-focused coping.]

\section{References}

\section{Books and Articles}

Agleton, P., K Wood, and A. Malcolm. HIV-Related Stigma, Discrrimination right andHuman Violations, Case Study of Successfull Program. UNAID Best Practice Collection, 2005. 
Ancok, D. "Injustice as a Source of Religious Radicalism In A TheoryBased Analysis Approach Justice In Psychology." Indonesian Journal of Psychology. No. 1 (2008).

Atkinson, RL, RC Atkinson, EE Sumarnoith, DJ Bem. Introduction to Psychology. Volume 2. Batam: Interaksara, n.d.

Anwar, Saifuddin, Human Attitude Theory and Measurement. Issue 2. Yogyakarta: Library Student, 1995.

Biesanz, J. and Biesanz, M. Introduction to Sociology. New Jersey: Prentice Hall Inc.. Englewood Cliffs, 1969.

Baswedan, Rashid anies., Analyzing Terrorism: Cultural and Rational. in http://www.arsip-milis.s5.com/politik4.htm .

Crenshaw, Martha. "Questions to Be Answered, Research to Be Done Knowledge to Be Applie." in Walter Reich (ed.). Origins Of Terrorism: Psychologies, ideologies, Theologies, States of Mind. Cambridge: Cambridge University Press, 1990.

Davidoff, LL. Psychological An Introduction. New York: McGraw, 1981.

Fauzi, Arifatul Choiri. News of Violence From Bali. Yogyakarta: LKiS, 2007.

Finkel, Elli J., \& Baumeister., Roy. F. Advanced social psychology: the state of the science. Oxford: Oxford University Press, 2010.

Green, AW. Sociology. An Analysis of Life in Modern Society. New York: Mc Graw-Hill Book Company, 1972.

Hendropriyono, AM, and Abdullah Machmud. Terrorism: Fundamentalist Christian, Jewish, Muslim. Jakarta: PT. Kompas Media Nusantara, , 2009.

Horton, P. and Hunt, CL. Sociology. Sixth Edition. London: Mc. GrawHill Book Company, 1984.

http://news.okezone.com/read/2011/05/24/337/460196/keluargaaa-cemas-dicap-teroris

Kamanto, Sunarto. Introductory Sociology: A Potpourri Flowers. Jakarta: Indonesian Torch Foundation, 1985.

Mack, R. and J. Pease. Sociolgy and Social Life . Fifth Edition. New York: D.Van Nostrand Company, 1973.

Milla, MN. "TeroriSumarnoe behavior." Anima Indonesian Psychological Journal, Vol 21, No. 3 (2008). 
Siti Nur Asiyah, et al.

Muladi. Paper Legal Aspects of Combating Terrorism. Yogyakarta, October 13, 2002.

Monita, Yulia. "Factors criminal acts of terrorism and mitigation strategies in Indonesia." Magazine Academic Law Forum. Volume 18, Number 2 (October 2008).

Panday, TR, S. Mishra, D. Chamjong, S. Pokhrel, \& N. Rawal. "Form and Patterns of Social Discrimination in Nepal, A Report." UNESCO Kathmandu Series Monographs and Working Papers. No. 8, 2006,

Sarwono, Sarlito Wirawan. Adolescent Psychology. Jakarta: King Grafindo Persada, 1997. 